\title{
Grundtvig and John Wesley - A Study of Convergence in Their Theologies
}

\author{
Jorgen Thaarup
}

John Wesley (1703-1791) and Nicolai Frederik Severin Grundtvig (1783-1872) were two very influential theologians, Wesley in eighteenth-century Anglican England and Grundtvig in nineteenth-century Lutheran Denmark. ${ }^{1}$ They became reformers of the Protestant concept of Christian thinking within their respective contexts of church and society. Wesley's theological ideas and ecclesiastical initiatives have spread internationally, forming and influencing new churches, schools, hospitals, and universities in many countries. Grundtvig's ideas have inspired theological and pedagogical understanding not only in Denmark but also, more broadly, in Scandinavia and internationally.

Wesley's and Grundtvig's numerous publications resemble the writings of other Christian theologians of their own traditions and contexts. But Wesley and Grundtvig also resemble each other in their specific aspects of theology and in their sources of inspiration. It is not difficult to see Wesley as an Anglican theologian of his time because his works demonstrate the influences of Arminianism and Puritanism, two strong theological forces within the Anglican tradition. Grundtvig, as a Lutheran theologian, is likewise a product of his own place and time. His writings bear the marks of old Lutheran orthodoxy and German Romanticism, a known influence on the Lutheran church of Denmark. In a number of themes, however, we find similar sources and convergent traits in the theologies of Wesley and Grundtvig (Thaarup 2016, 565).

1 This article is a presentation of the results of the PhD dissertation: Kristendommens Morgenstjerne. Konvergerende teologiske trek med baggrund i østlig tradition hos John Wesley og NFS Grundtvig, Göteborg 2015. 


\section{Convergence theologies}

This article focuses on Westley's and Grundtvig's convergence theology about what Christ has done for us. The idea of convergence is used in ecumenical studies to define the similar character and parallel thinking in different confessional theologies. Convergence should not be confused with consensus or congruence. Consensus occurs when theologies agree on exactly the same meaning, while congruence occurs when theologies have the same content and form. Convergence differs from these because it develops when theologies from different confessional backgrounds approach one another and move together in the same direction. Convergence theologies may never merge, but they move towards the same focal point on or behind the horizon.

The common source behind Wesley's and Grundtvig's theologies - the basis for their convergence - is a set of ideas and thoughts found among a group of Greek Church Fathers. Wesley and Grundtvig are not inspired by the same Church Fathers, but they both draw upon the tradition of Early Eastern Antiquity. Wesley's list of sources from the Eastern church includes Polycarp, Ignatius, Macarius, Gregor of Nyssa, Ephraem Syrus, Clement of Alexandria and the Apostolic Constitution. Grundtvig often draws from Irenæus and the Leiturgikón. In 1855, he translated and published Irenæus's Adversus Haereses $V$ with the Danish title "Om Kiødets Opstandelse og det evige Liv" and the liturgy of the Old Orthodox Church, the Leiturgikón, which he found in the Danish Royal Library in Copenhagen (Kjærgaard 2003, 227). Grundtvig learned about Irenæus and many of the patristic fathers by reading Eusebius' Church History. ${ }^{3}$

Another common source behind Wesley's and Grundtvig's theologies is the influence of Anglo-Saxon Christian culture, as identified in the writings of Bede and in Old English poetic manuscripts (Christensen-Görans-

${ }^{2}$ Unpublished list Kirkefadre i Grundtvigs Varker, Grundtvig Centeret, Vartov, shows that Grundtvig quoted Om Kiødets Opstandelse 65 times in three books, 69 times in 19 books, and an unknown number of times in his sermons.

${ }^{3}$ Grundtvig's knowledge about Irenæus and Christian Antiquity via Eusebius' Church History, see Grundtvig Haandbog i Middelalderens Historie, 1836/1862, 38-50. Grundtvig's reading of Justinus Martyr, Polycarp and Ignatius we find in Grundtvig Om Christendommens Sandhed 1826-27, see US IV, 646-647, 693694. 
son 1969, 1, 262-281). Wesley mentions the Celtic-Anglo-Saxon culture as the part of "Christian Antiquity," from where he took inspiration for his reformatory work. The Celtic-Anglo-Saxon theologian and historian Bede is mentioned several times in Wesley's writings. Wesley also recognizes the Eastern Church praxis of the Christian Year and the Easter celebration which were continued in England after the introduction of Latin Western Christianity, and he uses Bede as a source for his arguments (CL 3, 3-16; 13, 8-11). Grundtvig is very interested in Anglo-Saxon culture because the first and original Christian mission in Scandinavia was Anglo-Saxon, not Roman. Grundtvig's translations and use of early medieval English texts strongly marked the central parts of his theology.

It is possible to find sources that Wesley and Grundtvig directly use when treating some theological themes, because they identify their sources by name. Sometimes, commentaries themselves announce connections with sources and traditions, especially those represented by several Greek theologians. When Wesley writes that he studies Macarius, Ephraem Syrus, Bede, the Apostolic Constitution, and Clement of Alexandria, there is a direct indication of connection. When Grundtvig studies the writings of Irenæus, Bede, the Exeter Book, and the Leiturgikón, he signals connections. But often there are no indicated sources, only the content of the theology they are teaching. The obvious similarities between Wesley's and Grundtvig's theologies appear when they are evaluated against the background of the Eastern tradition. Some dominant thoughts of Eastern theologies have influenced Wesley and Grundtvig, marked their theologies, and formed their special characters.

In this article, we will see that Wesley interprets Christ's deeds as victories over the powers of Death, evilness, and corruption. These victories are the basis for human liberation and healing - an interpretation often found in the Eastern tradition (Link Ed. 1988, 78). Wesley refers to Christ's deeds as a ransom and redemption - an interpretation gathered from his reading of Irenæus, Clement of Alexandria, Origen, and The Apostolic Constitution. Grundtvig reflects on a number of texts from the AngloSaxon as found in the poetry of the Junius and Exeter Book Manuscripts and the writings of Bede, to interpret the Eastern explanation of Christ's death and resurrection. Grundtvig's emphasis on Eastern theology via the Celtic-Anglo-Saxon inspiration is further supported by the inspiration Grundtvig found in the Greek Leiturgikón. 


\section{Context shapes the focus on Eastern Christian tradition}

Wesley and Grundtvig stood against theological Deism and Rationalism. Wesley's showdown with Deistic thinking in 18th century England parallels Grundtvig's showdown with 19th century Rationalistic theology in Denmark. They regarded Deism and Rationalism as unrestrained, unscientific, and unorganized fantasies. And they found them unacceptable as guiding ideological frames, due to their rejection of given authorities to determine theories. Wesley and Grundtvig similarly critiqued them as, "castles in the air" and "Luft-Kasteller" (WW 23, 419:20-29; DV3, 203204, 235).

Immanuel Kant is subject to their critic. For Wesley and Grundtvig, the empirical approach to reality is the only way to the true knowledge and, especially, the experienced reality we find in history.

Wesley and Grundtvig have a remarkable theology of history as a mirror and a key to understand the present time. History gives us values and fundamental knowledge about the world and ourselves. Only history can help us find the meaning in life. New Testament texts, for example, have authority because of their place in history as a collection of people's experiences with their God; the New Testament was a collection of interpretations of the people's experiences of God's actions.

Wesley and Grundtvig's shared critique of theological Deism and Rationalism caused them to turn to history to find the knowledge needed to reform and renew Christian thinking for modernity. Christian antiquity was a valuable resource because in that time Christianity was not compromised by its close link to power in Europe. Wesley saw the Constantine state-church union as the main reason for the corruption of Christian institutions and officials. Grundtvig criticized the Latin era and culture, and he believed that the "Romans" spoiled much in Europe, including Christianity, multiple times. With their critique of contemporary ideologies and their knowledge of historical theology, it is understandable why Wesley and Grundtvig look to early Christian Antiquity and the Greek Church Fathers to find inspiration for the reformulation of the essence of Christianity. 


\section{Themes inspired by Early Greek theology}

In my dissertation Morningstar of Christianity [Kristendommens Morgenstjerne], I explain how Wesley and Grundtvig are inspired by different sources from the Early Greek theology. The themes are: 1) Dynamic anthropology, 2) The God who is reaching out, 3) The Fall or Original sin, 4) What Christ has done for us, 5) Two-sided conditions of divine-human relationship, 6) Salvation understood as growth, 7) and The Holy Trinity. And I analyze their answers to two questions. First, how did they understand the reconciling ministry of Christ? And second, what was the logical meaning of Christ's death and resurrection?

Wesley's view of Christ's fight against corruption, death, and Satan

Christians assert that God gives salvation to people because of Christ's sacrifice. ${ }^{4}$ Christ's ministry and his reconciliation between God and the world - these comprise the foundations upon which the theology is dependent. Other themes within Christian teaching depend directly on atonement. The word "atonement" is an interpretation of what Christ has done for people and for their salvation (Aulén 1930; Meistad 1992, 8991). The rationale is that the relationship between God and the world is broken because of sin which prevents human beings from reestablishing a good relationship with God. Because of that only God's initiative and His actions can form the world's relationship with God. These actions are seen in the incarnation in Jesus Christ and his death and resurrection. The inner logical explanation of how God's initiative and acts through the life and death of Christ can lead to the reestablishing of the good relationship with God is not clear (González 1989, 50-64).

The History of Christian Thoughts shows a number of hypothesis with different motives and priorities that determine the total understanding (Link Ed. 1988, 77-79; Richardson 1965). Among the Greek Fathers, e.g. Irenæus and Clement of Alexandria, we find the metaphor of Christ that his death was a ransom paid (lutron = to pay for prisoner's liberation) for humankind to free them from evil. Origen is specific in his use of Christ

4 The Nicene Creed, Faith and Order Paper no. 153, 1991, 10. 
as a ransom; he indicates that the ransom is paid to the devil to pay for the prisoners' freedom (González vol. 1, 1987, 222-225). Wesley often uses the metaphor that Christ by his death gives a ransom, but he never follows Origen's theory that the ransom is given to a devil or that a devil has any authority to set prisoners free. Even though Wesley doesn't dwell on the details of the exchange, he is constant in his explanation that Christ's death and resurrection constitute a ransom that leads to liberation ( $W W$ 12, 33-35). The action of Christ leads to human liberation from destruction and evil powers and to restoration, first, of a relationship with God and, second, of the human nature that was damaged by the power of sin. Christ's redemption reestablishes the relationship with God dramatically. Christ's death and resurrection are the crucial parts. Christ's adversaries are corruption, the power of death, and the devil. Christ fights and defeats His adversaries. Through Christ, the triune God fights against the adversary, and as the one God is triune, so is the adversary with the names Death, corruption, and the devil as its three parts. We find a fightand-victory motive in Wesley's understanding of Christ's actions on our behalf. Christ is triumphant. After the victory, death, corruption, and the devil exist in chains. The victory overshadows the fight, and resurrection takes dominion over his suffering, pain, and death on the cross. The whole action of Christ is a complete action of the triune God in Wesley's theology (Collins 2007, 99-10; Link Ed. 1988, 78).

In the Christian Library, Wesley quotes a long extract from Macarius' Homilies where the atonement of Christ is explained through a typological use of the lamb in the Exodus text and the meaning of the dove in the sacrificial act of the Temple. ${ }^{5}$ It differs from what the Eastern tradition proposes (Wesley 1754, note to Exodus 12:3; Wesley 1745, 11). The understanding of Christ's death and resurrection mentioned in this text is the same, if compared to the ideas of Irenæus and other Eastern church fathers. ${ }^{6}$ The action of God is completed, the claim of justification is broken, humanity has been liberated, and sins have been atoned by Christ through his death and resurrection (CL 1, 149-150).

\footnotetext{
${ }^{5}$ Notes to Numbers 6:11 f. and Leviticus 16:21.

${ }^{6}$ Ephraim Syrus and Gregor of Nyssa about Christ's fight in Hell and victory over the devil.
} 
A major question remains: How can Christ's death and resurrection lead to the reestablishment of the good relationship with God and cancel the harmfulness of sin? For Wesley, the answer is the key to interpretation. From Tertullian and Cypress to Augustin to Anselm of Canterbury, we find a tradition of interpretation where forensic aspects dominate and where judicial terms and principles play a major role (Aagaard 1994, 40). Because of sin, in this tradition, all human beings are guilty in the eyes of God. Guilt separates humanity from God. Moreover, when God is just and fair, He maintains the whole world with His justice. And Christ performs the action that is the foundation for human beings to be justified and freed from guilt. Anselm develops this forensic interpretation in his work Cur Deus Homo which includes the explanation that Christ, as a human, performs his act of salvation in relation to God (Lindroth 1935, 1-156. See also Link Ed. 1988, 78). In this forensic understanding of atonement, it is important to have a complete, inviolate principle of justice, but the act of God is broken because God the Father and God the Christ face each other in the act of reconciliation. It is in His capacity as a human being that Christ is sacrificed on the cross, and Christ's offering is received by God the Father (Anselm 1090/1978, 114-127; Radler 1988, 44-47, 182-227). Westley adopted this interpretation of the act of atonement from the Moravians and the Puritan Calvinistic both in and outside the Anglican Church.

The principle of justice is the major motive in this thinking, especially in his interpretation of Christ's acts. Christ's deeds are important for reconciliation of God and the world, and Christ is the one who leads to the reconciliation. Wesley describes the act of Christ as a fulfillment of reconciliation, but he never claims that those actions should have a deputy role for human beings, so that Christ takes on his shoulders the anger and punishment that God intends for mankind (Deschner 1960, 152-175). Wesley scholars agree that for Wesley Christ's compensation for human beings is important, but Wesley doesn't support the idea that Christ collected credits to be transferred to human beings.

Wesley does not believe that God's attitude towards human beings should be affected by a sacrifice. With reference to the Old Testament text about Abraham's sacrifice of Isaac, Wesley holds that even though God effected Abraham prepare for the sacrificial act, God was not interested in the sacrifice itself, only in Abraham's attitude (Wesley 1765, note to Gene- 
sis 22:12). After He tested Abraham, God didn't require a sacrifice, and he has not ever since. Likewise, Wesley turns against the understanding that the elements of suffering and punishment should have any positive effect on the God-human relationship (WW 4, 8:12-9:2). Christ doesn't need to atone for man's sins to make God willing to forgive and show human beings His mercy. God's nature is forgiving and merciful, and God's love overrules his justice in many situations without any other consequences. It is therefore God himself, not mankind, who breaks his justice. When Wesley speaks about Christ's deeds as a punishment, he means that Christ assumes the consequences of human sinfulness, corruption, and death, regardless of the inevitable death of the human body. Christ's deputy deed consists in voluntarily living a human life in its fullness from birth to death. By suffering and dying on the cross, God challenges corruption, death, and the devil through Christ. Through the resurrection of Christ, corruption, death, and the devil are totally defeated, and all their might and power are destroyed. Christ takes the penalty of sin upon himself (Maddox 1994, 95-97). It is not God's punishment, because God doesn't punish anyone, and it is not the devil's punishment, because the devil doesn't have the power to punish.

Using fight-and-victory terminology and forensic terminology, Wesley writes about Christ's deeds for humans through death and resurrection (Deschner 1960, 118-126; Collins 2007, 165-173). Fight-and-victory terminology appears when Wesley' explains salvation as a showdown between sinful corruption and individual sanctification and growth. Forensic terminology appears when Wesley explains salvation as justification and a showdown between sin and guilt. Wesley holds that, in principle, justification and sanctification are two different but inseparable things, like two sides of a coin (Lindström 1946, 83-104).

The relationship between Wesley's use of fight-and-victory terminology, on one side, and his use of forensic terminology, on the other, has been subject to many studies. Outler understands Wesley's thinking as a cross between Latin-Western and Greek-Eastern traditions:

... behind this Latin tradition lay the balancing, deepening influence of Greek Catholic spirituality (with its distinctive pneumatology that Wesley embraced wholeheartedly), with roots that run from Ignatius of Antioch through Irenaeus and Clement of Alexandria, to Macari- 
us, Gregory of Nyssa, Ephrem Syrus, and the great Eastern liturgies (Outler in $W W 1,36$ ).

From Outler's perspective, Wesley's theology belongs to the Western tradition, but with strong elements added from the Greek-Eastern tradition. When it comes to Wesley's use of the fight-and-victory motive, Outler claims that "these metaphors ... tend to outweigh the forensic ones that had dominated Western tradition since Anselm" (Outler in WW 1, 80). Ecumenical theology has bolstered this perspective of Wesley's dependency of the Eastern tradition. In Grundtvig, we will find that the fightand-victory trope is also strong.

\section{Victory and triumph}

To Wesley, the incarnation of Christ means that God not only became human in Christ's birth and life, but He also took upon himself the figure of sinful human beings. This understanding does not mean that Christ is sinful or has a sinful nature, but that he lives on earth under the conditions and consequences of sin. Incarnation in itself, when it is understood as an incarnation into sinful mankind, becomes a matter of accepting the punishment and penalty of sinful human beings. The consequences of sin are formulated in words of guilt and punishment which lead to the corruption of nature and death. Christ's death and descent into Hell is the necessary consequence of the incarnation. Without dying and descending into Hell, God would not have completely taken upon the sinful human figure in its fullness. When Christ's death and resurrection are seen as the deeds through which God reconciles the world with himself, Christ's words on the cross, "It is finished!" become an answer to the completion of both the incarnation and the atonement. When addressing incarnation and atonement, Wesley uses a fight-and-victory imagery (Collins 2007, 87-969). ${ }^{7}$ In accounts of Jesus's birth, life, and teachings, Wesley finds a battle against evil powers and all that destroy human life in the world. The fight is against a triune enemy of God and mankind. The final victory

\footnotetext{
7 Allchin 1989, 117, on Wesley's "Christus Victor motif in speaking of the atonement".
} 
happens with the death and resurrection of Christ. The death of Christ completes God's atonement and unites God with sinful mankind. It is a victory over corruption, death, and the devil whose strongest weapon, death, is meant to exact total destruction for Christ, but it doesn't. It is only an apparent victory because Christ, who is Life itself, cannot be defeated by the death, and he overcomes its power. The apparent victory of evil becomes its defeat, while Christ's defeat becomes his opportunity to show that he is the Lord of Life, and he is victorious. The outcome of Christ's death and resurrection is therefore, according to Wesley, victory over corruption, the death, and the devil.

Wesley sees victory every time the power of corruption, death, and the devil are broken in human beings and the world. It is in the description of human conversion, justification, regeneration, and sanctification that Wesley lifts up his perspective of Christ's victory and explains what salvation means. Because the Christian Gospel is an offering of salvation in Christ given to human beings in every present time, not only in the future somewhere, the victory of Christ will begin to take over in the life of human beings who are becoming Christian, and in the world, where, "Your Kingdom come and your will be done." Wesley strongly expresses motif of victory when he preaches on what it means to be a Christian and how Christianity influences different communities and the world. The eschatological reality in which God has defeated all evil and will recreate all that is hurt and corrupted begins to break through. It is called realized eschatological perspective (Williams 1960, 191-198). Collins summarizes Wesley's understanding in this way:

... the victory motif of conquering sin, death, Hell, and Satan as playing out not simply at the cross, but also in the ongoing transformation of human hearts in the context of the church, as Christ comes, judges, and then finally reigns without a rival. So important is this sanctifying work in believing hearts, in which grace is underscored and in which Christ holds sway, that Wesley envisions no eschatological fulfillment apart from it. In other words, it is precisely as Christ subdues all things to himself and utterly casts out all sin that everlasting righteousness is brought in - a righteousness that is not only the desire of the church but also the very perfection of the kingly role (Collins 2007, 113). 
Wesley describes Christ's victory over the powers of evil as a victory in this world. It follows that victory over the power of the devil and evil is linked to the cross and the resurrection of Christ and not to a future fight in the afterlife. Wesley insisted that Christ's deeds are planted in this historical world and that the Christ-versus-evil battleground is this world. It is also because of his understanding of Hades and Hell. Wesley follows the Apostles' Creed which states that Christ, after his death and burial, descended to the place, where the dead people are. He went descendit ad inferna. ${ }^{8}$

The incarnation of Christ means that Christ becomes human and lives life as sinful people do, all the way to death and into the innermost of death. The place where the dead people are during the time before the morning of the resurrection is Hades, corresponding to the Apostles' Creed's "inferna." Christ comes to Hades, "... Hades where the souls of wicked men reside" ( $W W 4,8: 13-14)$. Wesley follows, however, the understanding that Hades is a land of the dead where the dead souls reside until the morning of resurrection, when they are to be united with their resurrected bodies before continuing into the new and recreated world (WW4, 8:8-9:15). Hades is like an antechamber or forecourt to Hell and Paradise, and it is not identical with Hell (Collins 2007, 319). The idea that Christ descends into Hades, to the land of the dead and the antechamber to Hell where the dead souls reside, can be found in Wesley's writings (WW4, 189:27-30).

In his sermon on the biblical text on the rich man and Lazarus, Wesley asks if a resurrected person could testify in a way that might impact the lives of the living. Wesley writes that the answer is Christ himself, because $\mathrm{He}$ is the one who has returned in his resurrection from the land of the dead.

Christ's fight and victory over death and the power of the devil happen on cross, in his time in Hades, and the resurrection. Wesley's conviction that Christ doesn't reside in Hell is also stimulated by the words of Jesus to another condemned man on the cross when He says, "Today shalt thou be with me in Paradise," "9 and by Peter in his Pentecostal preaching, Acts 2:27, where it is said - mirroring David's prophecy about Christ's death - "For thou wilt not leave my soul in Hades, neither wilt thou suffer thy Holy One to see corruption" (Wesley 1754, notes to Acts 2:27). Christ is a ransom that leads to liberation; Christ defeats the power of death and

${ }^{8}$ According to Book of Common Prayer, Art. Rel. III, 685.

${ }^{9}$ Luke 23:43. 
leads prisoners to freedom (Wesley 1754 , notes to 1 Peter 3:18-20). ${ }^{10}$ Even though Wesley did not fully follow the ideas in the Eastern pictorial interpretation of the atoning deeds of Christ, his words and formulations bear the clear marks of this thinking (Aulén 1930, $78 \mathrm{ff}$.). ${ }^{11}$

Wesley understands that Christ's descent into Hades meant that Christ preached salvation for people in the land of death. ${ }^{12}$ That Christ shall "not leave [his] soul" in Hades is not the same as His not visiting Hades. Grundtvig draws the same line for his understanding as Wesley does of Christ in the land of the dead by stating several times that Christ was a guest in Hell. ${ }^{13}$ Christ does not belong to Hell, and even though he was there and fought a battle, it was as a guest, on his way from before to after. However, Wesley imagines how Christ descended into Hades and preached there in the hymn "Jesu, thy blood and righteousness" ( $W W 7$, 309:37-311:443) which was rewritten in Danish as "O Krist, dit blods, din retfærds magt” (Salmer \& Sange 2006, 612-613). ${ }^{14}$

The effect of Christ's fight and victory is often formulated in figurative language about prisoners' liberation and His victory over evil, corruption, death, and the devil. Often, as scholars focus on the messages of triumph and victory in the Gospel, attention turns to who or what Christ is fighting against and what the battle is about (WW 7,140$)$. The dying Lord is fighting a battle for humanity, and during this battle, $\mathrm{He}$ is victorious. That is the reason why God is worthy of all praises for what he, in his mercy, has done for all human beings (WW 7, 141). Victory means that people can look back at their former states as prisoners and slaves. Because of the victory, they are set free from pain and have left death, Hell, grief, and suffering behind $(W W 7,141) .{ }^{15}$ Death is swallowed by life itself. It is a result of Christ's descent and ascent. Thus, it is for all people to whom the victory of Christ is a new paradigm for life and a foretaste of the coming Paradise.

The fight-and-victory motif is found in many sermons and hymns. One of the hymns, Wesley's "Head of thy church triumphant" (Wesley 1745

\footnotetext{
10 See also: $W W 4,16: 19-17: 29$.

11 See also: Wesley, 1737, 46-47, no. VIII.

12 The Gospel of Peter 10:42.

13 See GSV 1.2, 474: "Guds Søn haver Helvede giæstet!” and Grundtvig 1865, 45: “... en Giæst, Kommet fra de Dødes Rige.”

14 Danish text P.H. Larsen (1877-1958).

15 See also Wesley (1779/1876), 666.
} 
1847, 239-240), was known by Grundtvig in 1836, when he rewrote it in Danish, "Seier-Kirkens Høvding bold" (GVS 2, 630-631). One final example of Eastern Greek terminology used by Wesley is the Wesleyan hymn "Our Lord is risen from the dead" (Wesley, 1779/1876, no. 557), another hymn Grundtvig rewrote in Danish in 1837 and published with the title "Vor Frelser opstod fra de Døde" (GVS 2, 484-485). ${ }^{16}$ One of Wesley's most widespread Easter hymns, "Christ, the Lord, is risen today," speaks about the redemption of Christ, His "triumph", and "victory." He mocks Hell, death, and the grave because they have lost (Wesley $1779 / 1876,652-653) .{ }^{17}$

Grundtvig: Christ's fight against sin, death, and the great Tyrant

Throughout Grundtvig's authorship, we find evidence that Grundtvig, to a great extent, follows Eastern Greek thinking about the interpretation of what Christ has done for us. Aulén talks about the classic atonement hypothesis where Christ is understood as the one who won victory over the powers of corruption and death, in contrast to the Latin and forensic atonement hypothesis where focus is on law and justice (Aulén 1930, 38-69; 141-171; Bjerg 2002, 116). In his early authorship, Grundtvig edited and published the periodical Danne-Virke where his Easter play, Paaske-Lilien, was first printed. In the play, Grundtvig lets the angels sing on Easter morning at the grave:

The Dragon is bonded,

Death has lost its Sting,

The Lion has won,

Life is the lot for the Believers

(...) Defy the bond of the Grave and the tricks of the Satan

(...) Offer mockery to the Grave and defy the Dead! $!^{18}$

16 See that Grundtvig in note on page 484 refers to Wesley.

17 Salmer \& Sange (2006), no. 168, 236-237.

18 "Dragen er bundet, Døden har mistet sin Brod, Løven har vundet, Liv er de Troendes Lod. (...) Trods Gravens Baand og Satans List ... Byd Graven Spot og Døden Trods!" (DV II, 317-318; 321). 
The dragon, death, and Satan represent the opponent whom Christ, the Lion (GVS 1.2, 630-631), ${ }^{19}$ has conquered by binding him and holding the rope of the grave. Through these actions, the believer has access to life and can defy death and mock the grave. In very few words, Grundtvig gives his explanation of Christ's suffering, death, and resurrection by using Eastern thought and not the Latin forensic terminology.

The words used in description of Christ's attributes are about victory and conquering and especially stating that Christ is a hero. The description of Christ's suffering and death frames those events as heroic deeds that demanded a lot from Christ, but also gave him the total victory. ${ }^{20}$ One of Grundtvig's Christmas hymns, "The choir of God's angles are singing delectable together," ${ }^{21}$ explains the purpose of the newborn Christ by saying that He "Is our hero and our Lord" who has come to the world "In [God's] image" to recreate "Us again."22 The heroic deed of Christ is seen as taking place during his whole life and not limited to the drama of suffering, crucifixion, and resurrection. Christ's deeds are the foundation of salvation, offered to all people, so that the image of God may be recreated in believers. In other hymns, Grundtvig views salvation as forgiveness of human $\sin ^{23}$

Human life, too, is a battle. During that battle, the knowledge of Christ's victory is a resource; faith in Him gives believers the confidence needed to give them victory in their fights and battles. The story of Christ ends in a way that includes death, and death is not understood as a final end, but as the opening to a new era. Every living human being faces the end of life eventually, but the end is also an open door to something new. According to Grundtvig, Christian "awakening" 24 allows people of faith

19 Rev 5:5b. Gen 49:9.

20 In 1826, Grundtvig writes: “... Jesu Selv-Opoffrelse paa Korset, som den store Helte-Gjerning, hvormed han frelste os, saa Troen derpaa er Overgangen fra de Dødes Rige til de Levendes Land” (US IV, 486).

21 GSV, 4.1, 249: "Guds Engle i Flok! Synger liflig i Kor."

22 "vor Helt og vor Herre", "i Billede sit", "os paany".

23 Grundtvig in Om Christendommens Sandhed 1826-1827: “... det var ikke for sin egen, men for sine Troendes Skyld, vor Jesus døde, og at denne Hans Død var Vilkaaret for den Synds-Forladelse vi i vor Troes-Bekjendelse ophøie (...) at Christi, Guds Søn, frivillige Død (...) kan udvirke hans Troende Synds-Forladelse!” (US IV, 630).

24 “opvaagnelse." 
to live, borrow, and take over the end of life from Christ. They borrow from His death and resurrection and make His end of life their own story. This is "the hope" of the "incorruptible," and it is open to everything $\mathrm{He}$ has "prepared to us." 25

Grundtvig's most concentrated and complete interpretation of Christ's deeds for humanity can be found in his sermons. Here, he focuses on the idea that the Father and the Son are united and driven by love to "atone [for] the sin of the World" and to overcome the great tyrant, death, and break the deadly chains that bind all people. This act of the unified Father and Son is an invitation to all people to access life, now and everlasting. ${ }^{26}$

Grundtvig uses fight-and-victory terminology to describe people who are living sinfully and facing death because of it. He calls them prisoners of death, evil, and the Evil One. Christ himself was never a prisoner of neither anything nor anyone. He accepted the conditions of a human life with the purpose of destroying the powers of corruption. ${ }^{27}$ There are many results of Christ's deeds for us, but the greatest is our liberation and victory. He is the one who conquered, and he offers the spoils of victory to human beings. ${ }^{28}$

Grundtvig easily combines Old Testament images of Jahwes fighting with New Testament images of Christ's battle. Jahwes descended to

25 Grundtvig Den christelige Kamp 1825: “... vi skal kun glæde os over Seiren, Jesus vandt, da Han førde Liv og Uforkrænkelighed igjen for Lyset, da Han i Graven, hvoraf Han seierrig opstod, beredte os (...) en glad Opvaagnelse (...). Ja, dette store, uforkrænkelige Haab, det er den Salighedens Hjelm, der holder de Christnes Hoved opreist under Kampen (...)" (US IV, 439).

26 Grundtvig Om Kiødets Opstandelse og det evige Liv 1855, about "Tyranniets Tid." (Grundtvig 1855, 87). See also GVS 1.2, no. 254, 483-484, about the fallen Thyrant. Grundtvig Pradikener $i$ Vartov, vol. 2, 169-170.

27 "Han som havde reddet Andre af Dødens Vold, kunde umuelig selv blive dens Rov (...) thi jeg har Magt til at sætte Livet til og tage det igjen, (...) det var for at løskiøbe os der Alle som Syndere, var Dødens Fanger, har han selv forklaret sin frivillige Død, forklaret den af det, kun for os dunkle, men i sig selv evig soleklare Dyb, hvis Navn er Kierlighed” (GPV II, 169).

28 Grundtvig Om den sande Christendom 1826: “... vor almægtige Skyts-Aand, og med vor usynlige Konge, der knuser Konger som Leerkar, og rører ved Bjergene, saa de henflyde som Vox for Hans Ansigt, og vidner, at den almægtige Jord-Drot ogsaa er den Himmel-Drot, vi i ham tilbede! (...) thi Seiren er vundet, Riget er frelst, mens vi sov, af Ham, der ikke slummer men vaager altid over Israel (...) da vi herefter (...) levende tage Deel i Hans Kamp og Seier” (US IV, 550). 
Mount Horeb to meet with Moses ${ }^{29}$ or the peoples in the days of Jer$e^{e m i a}{ }^{30}$ who were like broken vessels. Grundtvig's hymn "Daniel in the Lions' Pit" 31 reflects the theme of Christ's death and resurrection. In the same way, "The angels of God" bound "The gabs of the Lions," as did the "Savior in the Snake-Garden," and in contrary to "the Sinful-Nature's Order," He didn't "Dissolve." Therefore, "The friends of Jesus" are able "this Evening (...) smile at the Death," because they "Shall arise shining in the dawn." 32 The battle and the victory are connected to the Easter drama; Good Friday and Easter Morning are the exponents of God's victory over the powers of destruction and corruption. Grundtvig's use of other stories of God's battles and victories gives his presentation a cosmic and overall inclusive character.

Grundtvig uses another Old Testament image in his Easter hymn "Remove the black Cross from the Grave" ${ }^{33}$ where he compares the resurrection of Christ with the Phoenix bird ${ }^{34}$ who dies but arises again from its own ashes. He says, "Palm-Bird for an ash jar! Praise songs for painful sighs" and continues connecting the human resurrection with the likeness of the wings of the Phoenix that are growing out again, "Growing of the Bird-Wings of the Soul!" ${ }^{5}$ He also writes, "Like the Sun-Bird you will be young again!"36

Grundtvig's ideas of Christ as the hero and the one who redeems those living under the conditions of death are developed strongly in Grundtvig's description of what happened to Christ during the three days between his death on Good Friday and his resurrection on Easter Morning. He writes,

29 Deut 4:11-12. Psalm 97:5.

30 Jeremias 19.

31 “Daniel i Løver-Kulen” (GVS 1.2, no. 307, 566-567).

32 "Guds engle”, "Løvers Munde”, "Frelseren i Orme-Gaarden”, "Syn-Naturens Orden”, “Opløsning”, “Jesu Venner”, “i Kveld ad Døden smile”, "Skal i Gry opstaae med Glands."

33 "Tag det sorte Kors fra Graven," GVS 4.1, no. 124, 155-157.

34 Job 28:18, LXX Ps 92:13, 1 Clement 25:1-5. Grundtvig recognizes that in Ps 103 the Phenix bird has been an eagle, but the Phenix motif is still behind. See Grundtvig 1840, 16. See WW7, 155:13-16, for Wesley's use of the Phenix motif. 35 "Palmefugl for Askekrukke! Frydesang for hule sukke", "Voxer Sjælens Fuglevinger!", "Sol-Fuglen lig, bliver ung du igjen!" (GVS 4.1, no. 124, 155; no. 147, 278).

36 GSV 1.1, no. 64, verse 3, 155. 
"He has ransomed you among the slaves of Hell." 37 This understanding of ransoming unfolds in major figurative language on the mythological drama between good and evil. The fight is going on behind the visible world. ${ }^{38}$ These insights do not change: The logical understanding of the cross remains a riddle that only a faithful believer can solve.

The phrase in the Apostolic Creed, "Descended to the dead," descendit ad inferna, refers to Christ's movement to the place where the dead gather after the soul and body are separated. Grundtvig has, like Wesley, many considerations about how Christ's presence in the underworld can be understood. ${ }^{39}$ Christ doesn't arrive as a damned person and, even though he took upon himself the sin and the guilt of the world, he was innocent. He doesn't arrive as a gleeful person who can prove His own innocence and victory to the damned persons so they can see what they have missed because of their lack of faith. Grundtvig turns against the understanding that Christ is a victim or judge; instead, He comes voluntarily and to save. As part of the reflections, Grundtvig muses on the differences between Hades, the land of the Dead, Hell, and Paradise. Christ descends into the place where the Evil One is powerful. Only there can he fight the great opponent and proclaim liberty to those imprisoned there, those who have faith in him as their savior (CP III, 176-195). ${ }^{40}$

Throughout Grundtvig's authorship are descriptions of Christ's descent and ascent. ${ }^{41}$ Christ is the hero because of his death and interment and because, through his resurrection, he was victorious and able to free prisoners in his triumphant march. ${ }^{42}$

37 "Løskiøbt har Han dig blandt Helvedes fanger," GVS 1.1, no. 64, verse 3, 155. ${ }^{38}$ Grundtvig Søndags-Bogen, sermon on Matt. 28:1-10: “... hvad der virkelig skedte paa Jorden, da Herrens Engel foer ned fra Himmelen, oplukkende med Kongens Nøgel den forseiglede Dør mellem de Dødes Rige og de Levendes Land, fordi Livets Fyrste, som ved en Feiltagelse, var kommet til at ligge i Dødens Lænker, som da nødvendig maatte sprænges" (US V, 217).

39 “... han ogsaa nedfoer til det Under-Jordiske, (...) opholdt han sig tre Dage i de Dødes Rige” (Grundtvig 1855, 104-106, 105).

40 Sermon IX Christi Nedfart til Helvede 1. Petersbrev 3:18-22.

${ }^{41}$ Grundtvig Ved Tusindaars-Festen 1826: "Guds egen Søn, o glem det ei! Gik til de Dødes Rige, Kun for at du, paa Livets Vei, Til Lysets Hjem kan stige!” (US IV, 744).

${ }^{42}$ Grundtvig in Søndags-Bogen, sermon on Acts 2:1-11: "Helten, der kommer seierrig tilbage fra de Dødes Rige, førende Døden og Helvede med sig i Lænker 
Christ's fight in the land of the dead leads believers to understand that evil has been overcome. Evil has two faces: Death and corruption. They are explained as phenomena, but they are also personified. In this way, the opponent of Christ has the character of both a personal and evil power. The clearest personification of evilness is found when Grundtvig describes the fight as a duel with allusion to the duels found in the Bible. Grundtvig writes, "The Hero who won the victory and bound the Strong one took the armor he was depending on, plundered his Palace and shared the loot with his friends!" 43 Likewise, Christ's battle is seen as the fulfillment of the promise made to mankind after the fall that the offspring of the woman "Shall crush the Head of the Snake, but you shall be bite in your heel." 44

The suffering and the fight are portrayed dramatically, but Christ's victory, triumph, and heroic exit after the fight are prioritized. ${ }^{45}$ Even though the pain and death that occur on Good Friday is comprehensive, and the battle in the land of the dead is crucial to explanations of what Christ has done for us, the total dominant perspective is found in Grundtvig's interpretation of the resurrection on Easter morning. He writes, we "welcome you with the crown of victory, in the Light of the battle in the hidden place...Welcome to the plain place, away from Shadow Land in

(...) naar vi kun har den Tro, at Død er Syndens Sold, men det evige Liv Guds Naade-Gave i Christo Jesu, vor Herre, og jeg tør vel mene, at Herrens Opstandelse staaer ei i større Glands for noget Menneske-Øie, end for Unger-Svendens, hvem Døds-Tanken vakde af hans søde Drømme om Jord-Livets Herlighed, eller hvis Hjerte vaandede sig under Følelsen af Verdens-Livets Tomhed, naar han under sine stille Betragtninger faaer Syn paa Helten, der kommer seierrig tilbage fra de Dødes Rige, førende Døden og Helvede med sig i Lænker, og udstrækkende sin milde Haand med Livets Brød og med Salighedens Kalk, til Muldets Frænder i Græde-Dalen!” (US V, 209).

43 Allusion of Matt 12:29: “ $\ldots$ den Helt der overvandt og bandt den Stærke, tog hans fulde Rustning, som han forlod sig paa, udplyndrede hans Palads og deelde Byttet med sine Venner!" (GPV2, 171).

${ }^{44}$ Genesis 3:15. Grundtvig Om Kiødets Opstandelse og det evige Liv about Christ as the "Snake-Crasher": "skal sønderknuse (Slangens) dit Hoved, men du skal sønderknuse hans hæl" (Grundtvig 1855, 71-75).

45 "See, at denne Fader-Kiærlighed og til denne Gienløsningens Helte-Gerning gav Han sin eenbaarne Søn, den heltemodige Løve og det taalmodige Lam, som knuste Slangens Hoved (...)" (GPVII, 253). 
the Depths!"46 The pain, death, and struggle are always seen from the retrospective of the victory in the resurrection.

Compared to Grundtvig's pictorial and metaphoric language on the motif of fight and victory, Wesley's language is plainer and more muffled. This is not because Wesley is inarticulate or imprecise, but because Grundtvig is more emotionally powerful and uses so many expressions taken either directly from the old Greek liturgy and Fathers or from the Celtic-Anglo-Saxon poems.

\section{Death and Hell in chains}

Grundtvig's study of other sources influenced by the Eastern Greek fathers catalyzes his own writings. In his work on Beowulf, after Thorkelin's edition of the poem appeared in 1815, Grundtvig shows in his commentary on the poem that he understands it through a Christian lens where the heathen events are structured and put into a providential framework. There are several levels of meaning in this poem. Beowulf - Grundtvig calls him Bjovulf - defeats the evil powers, and the poem is "a great Pictorial Word (...) the Word is, as Scripture teaches, and as we now are able to understand, the highest and deepest Expression of the Revelation of Life, and this whole Story must be understood as the Words coming to Fight and Victory." ${ }^{\prime 7}$ Grundtvig understands that Bjovulf's Drape is a "Fundamental-story" or an "Epos" that dominates and gives the patterns for other stories and imaginations. Christianity has shown by its worldwide popularity that it has a powerful influence on other cultures and mythologies. Bjovulf's fight and victory are, in this perspective, a reproduction of the Christian, "Fundamental-story" on the fight and victory of truth (Grundtvig 1875, 96).

Grundtvig understands the life of Christ on Earth as the Word made flesh, and Grundtvig sees the event as an image of the fight and victory

46 "Velkommen seierkronet, I lys fra Slag i Løn (...) Velkommen paa det Jævne, Fra Dybets Skyggedal!” (GPVII, 175).

47 GPV II 273: "et stort Billed-Ord (...)Ordet er, som Skriften lærer, og som vu nu kan fatte, det høiste og dybeste Udtryk for Livets Aabenbarelse, og den hele Historie maa betragtes som Ordets Kamp til Seier." 
of truth. Spiritually understood, the event has created the only true epic in history. ${ }^{48}$

Grundtvig is convinced that Cædmon or someone closely related to him was the poet of Bjovulf's Drape. This conviction may have stimulated Grundtvig's interest in the Anglo-Saxon Christianity which, in part, compelled him to journey to England three times between 1829 and 1831. During those visits, he learned more about the writings of Cædmon, Bede, and Cynewulf and texts of the Exeter-Book, e.g. the Messiaden. ${ }^{49}$ Knowledge of these writings gives Grundtvig an even more clear understanding of what Christ has done, "For us all and for our salvation." 50

The most coherent depiction of Christ's descent into the land of the dead and what happened there is found in "Ragna-Rok" where Grundtvig retells "Cædmon's Hymn" from Bede's Ecclesiastical History of the English

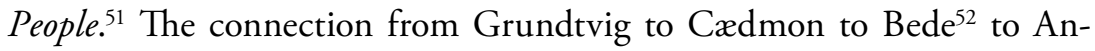
glo-Saxon Christianity in England is also the connection to the Eastern and Greek Christian Antiquity (Hieatt 1983, xxviii, xxxvii) from where we have knowledge about Christ's death and resurrection. The story is presented as a mythological battle between God and the devil, between life and death, and between Christ and Satan. Grundtvig takes inspiration from Eastern and Greek thinking when he writes about Christ's fight against the powers of Hell and how Christ empties Hell, freeing the prisoners and leading them back to Paradise. Grundtvig's first great hymn on Christ's descent to the land of the dead is "I kveld blev der banket paa Helvedes Port," ${ }^{33}$ a twenty-verse narrative poem. He writes, "The herald was strong" when he knocked "on the gate of Hell" and announced to "the dragons of Hell" that he has come to trample "on lizards and drag-

48 Om Bjovulfs Drape: "Christi Liv paa Jorden, Ordets Vandring i Kiød, er en Begivenhed, der ikke blot afbilder, men indeholder Sandheds Kamp og Seier, og som synes, aandig beskuet, at maatte frembringe det eneste sande Epos, der i Historien lader sig Skabe" (DV II, 275).

49 See Bradley 1998.

50 WCC, Faith and Order paper no. 153 (1991), 10.

51 Noack, 1983, 68-72. See DV II, Om Bjovulfs Drape, 277. See also Allchin in Grundtvig-Studier 2001, 31-40.

52 Bede Venerabilis (ca. 672-735). Christensen-Göransson I 1969, 268-269.

53 GSV1.2, no. 243, 471-474. Grundtvig's note on page 471: "Efter Angel-Sachseren hos Cædmon." "Knocking on the door of Hell tonight." See also Kjærgaard 2003, 225-227. 
ons" and to crush "the viper-Snake" and "the wolf of Hell." His arrival wakes up all the prisoners and, "at that moment the Sun of Heaven was shining in Hell." "Our Savior" calls, "Adam, where are you?" Then, "Eve" appears, and the couple has conversations about what went wrong, and why they ended up in Hell. "Now, from Hell [goes] the Lord," together with "a Crowd" of those he has found in Hell. The hymn says, "The Devil now falls ten-thousand miles into the deepest place" and only "Death was sitting in Hell" left behind, when "our Savior, innocently crucified," triumphantly returned, and the doors of Hell were closed when "the Son of God ... stood up on the third Day" after he had "visited Hell!"

Grundtvig understands Christ's deeds as acts of liberation and redemption; Christ intends to give freedom to as many as possible. These sentiments are found in another hymn of Grundtvig's from 1837; it is a rewriting of Montgomery's "O Spirit of the Living God"55 as "Du, som gaaer ud fra den levende Gud." ${ }^{6}$ Verse six of the poem states that the triune God is behind an act of salvation that redeems all.

In the poem "I Kveld blev der banket paa Helvedes Port," Grundtvig rewrites the story of Christ's descent, His preaching to the prisoners, and His victory over death and the devil. Noack adds the headline "Storm of Hell" to a section of the poem that Grundtvig thinks is written by Cædmon. ${ }^{57}$ Noack assigns the next section of the Messiade the header the "ascension to Heaven." ${ }^{8}$ Grundtvig was so inspired by these sections of

54 "Herolden var stærk", "paa Helvedes Port", "Helvedes Kryb”, "paa Øgler og Drager", "Hug-Ormen", "Helvedes Ulv", "da skinnede i Helvede Himmerigs Soel", "vor Frelser-Mand", "Adam, hvor er du?", "Eva", "min Søn og min Herre", "Fra Helvede steg nu den Herre", "en Skare", "Titusinde Mile end dybere ned sank Djævle", "Død sad i Helved”, "vor Frelser, uskyldig korsfæstet", "Guds Søn”, "opstod paa den tredje Dag", "Helvede giæstet!"

55 Hymns and Psalms 1983, no. 322. James Montgomery (1771-1853). Methodist from Scotland, editor and hymn writer.

56 GSV 1.2, no. 360, 625-627. Grundtvig's note on page 625: Montgomery's "O Spirit of the Living God" imitated. See also NFS Grundtvigs Kirke-Salmebog no. 227. Grundtvig's knowledge about Montgomery's hymns is from his travel in England 1829-31, see Kjærgaard 2003, 300. See also Balslev-Clausen's article in Grundtvig-Studier 1983, 42-67.

57 "Helvedstorm." GSV2, no. 132, 382-384 verse 2: "Frelseren laa i sorten Jord," verse 3: "Han i Gravens Land, Stormede Dødens Taarne."

58 Ibid. "Himmelfart." 
the Messiade that he wrote the hymn "Kommer sjæle, dyrekiøbte." ${ }^{59} \mathrm{He}$ understood that Cynewulf was behind this section of the Messiaden. ${ }^{60}$ This hymn, in eight verses, focuses on Christ's ascent. Our "Savior, the Creator of the World and the Judge of the World" is like a "Redeemer of the string of death and all the Devil's Fright and Cruelty." Christ comes "victoriously from the deepest place." "The Souls who have a high price," those who "before [were] lost, but now are found," are now whole "Redeemed (...) People." He "came from Hell" and "[ascended] from the Valley of Lamentation" to Heaven where the "welcome-song from the army of heaven" received "Him and many millions, [who were] paid for with His blood." Grundtvig provides a coherent narrative about ascension from Hell to Paradise, beginning on Good Friday and continuing until the Ascension Day of Christ. ${ }^{61}$

We find the same understanding in Grundtvig's hymn "To the home of Dead our Hero descend." ${ }^{2}$ The Lord is "our Hero," who "descend[s] into Hell to overthrow the throne of death" and "defeat[ed] the strong enemy's mockery." Christ is also called "a preacher with the language of spirits," who appeals to the faith of the prisoners. Now he is on his way "in triumph out of Hell" and frees "deeply happy prisoners" to follow Him "from Hell to Paradise." Nobody asks, "What do we understand?" Everyone declares, "Our faith, only the Lord's and our own!"

59 GSV 1.2, no. 244, 474-475. Note: Af den Angelsachsiske Messiade i Exeter-Bogen. Kjærgaard 2003, 262, Kynewulf, Messiade, ca. 800 AC. See also NFS Grundtvigs Kirke-Salmebog no. 214. "Come, the Souls, who have a high price."

60 Noack 1983, 101-104.

61 "Frelser-Mand, Verdens Skaber og Verdens Dommer", "Løseren af Dødens Baand og Alle Djæules Skræk og Gru”, "Seierrig fra Dybet”, "Sjæle, dyrekiøbte”, "Før fortabte, men fundet nu”, "Folk", “igienløste”, "Kom fra Hel”, "Stigende fra Jammer-Dale", "Himmel-Hærens Velkomst-Sang", "Ham og mange Millioner, Dyrekiøbte med Hans Blod" (GVS 1.2, no. 244, 474-475).

62 "Til Helvede vor Drot nedfoer." GVS 1.1, no. 47, 127-128: "Our Hero descend into Hell:" "vor Drot", "nedfoer til Helvede”, "at styrte Dødens Trone om”, "Neddæmp den stærke Fiendes Spot”, "En Prædikant paa Aanders Sprog”, "vor Herres Nadfart Præk", "Fra Helved i Triumf”, "Fanger sjæleglad”, "Fra Helvede til Himmerig”, "hvad vi forstaae!", “vor Tro, Kun Herrens og vort Eget!”. 
In a later hymn, "Til Dødningshjem vor Drot nedf'or,"63 Grundtvig repeats the theme that "the savior is a preacher" to those "imprisoned" and to those who "before the candle of Christianity was lightened" were in "the gentile darkness," or those worried Christian people who needed comfort, for "in the land of death, even the Word of Life has found its Way and Voice."

Along with his Anglo-Saxon sources and contemporary sources, Greek liturgy provided Grundtvig with inspiration for descriptions of the deeds of Christ. Scholars have called this inspiration Grundtvig's Greek Awakening. ${ }^{64}$ Grundtvig's studies of the Greek liturgy and his attention to the Eastern Greek atonement hypothesis stand behind his hymns. ${ }^{65}$ The clearest reflection of a classic Eastern Greek atonement hypothesis appears in "Today the Hell is Moaning and Groaning" In this hymn, Death and Hell ask questions that are answered by those who, after the resurrection, have seen the fight and victory of the "Divine Man." In "Helten, som os hjalp af Nød," ${ }^{\prime 67}$ Grundtvig writes that "the Hero" forces Death to withdraw. Hell is given several names like "the Snake-Pit" where "the Dark Hero" has his nest. Grundtvig alludes to Biblical parables about the lost coin and the lost sheep ${ }^{68}$ to explain that the Hero "eagerly looked for" and "searched high and low" for "his penny and his sheep." The image of "the strong giant (...) caught in his own nets" is taken from the fowlernet metaphor used by Gregory the Great in a later version of Gregory of Nyssa's hook metaphor with the same meaning; "the Snake," now caught, has to be stripped of his "Helmet and Breastplate-Armor." "The Son of Mary" has "Plundered Satan's Fortress" and "Shared the Plunder with the People." The whole drama seems as if it takes place in present time because

${ }^{63}$ GVS 5.2, no. 209, 356-357. Written 1860-1862. "Frelseren er Prædikant", "i det store Fangenskab", "Før Christendommens Lys blev tændt", "I Hedenskabens Mørke", "At i de Dødes Rige, Dog Livets Ord fandt Vei og Røst."

${ }^{64}$ See Thodberg 1983, 180-184.

${ }^{65}$ Elbek 1960, 23, 59-69, 149.

66 "I Dag sukker Helved og klager." GSV 1.2, no. 218, 441-443.

${ }^{67}$ GVS 1.2, no. 229, 451-452: The Hero helped us out of distress.

${ }^{68}$ Luke 15:1-10. 
the risen one is "waving to us with the sign of victory," as we celebrate the victory. ${ }^{69}$

Grundtvig wrote the hymns "The Angle like a lightning"70 and "The Lord wake up of sleep"71 while he studied the Leiturgikón Easter liturgy. Both reflect on the Death of Christ from the perspective of the resurrection. Death has fled from him ("Death from Him has escaped") because of "great things, our God has done for us (...) in the land of the Dead." Christ left "the Cave" when "He raised himself in glory" and took "Adam's fallen stock" from death because "the caves he emptied." The hymn says that "Christ is risen from the Dead," and "Hell is exploded." "In his death Christ has tread on the neck of Death" and "is risen from the Dead" for "each and every mortally Human Being," here and now. ${ }^{72}$

The theological development found in Grundtvig's poetry parallels what is found in his preaching during the same period. In his Easter Day sermon of 1837 , he uses the fight-and-victory motif to express his understanding of Christ's deed, but he also describes the resurrection as an event taking place in current time. ${ }^{73}$ The resurrection is something always present. In the congregational celebration of Easter is the cosmic drama of resurrection, regeneration, and restoration of what is broken. ${ }^{74}$

Returning home after his last journey to England in 1843, Grundtvig writes "Easter morning quenches the thirst of sorrow," 75 a nine-verse hymn about "the Lord's" fight against "Darkness" and "The Dead." Now,

69 “Helten”, “Orme-Gaard”, “Mørkhjelms-Drotten”, "Flittig opsøgde”, “med Lys og Lygte”, "sin Penning og sit Faar”, "Den Jette stærk”, "Fanget i sit eget Garn”, "Slangen”, "Hjelm og Brynje-Særk, Plyndret blev hans Bolig”, "Kvindens Sæd, Marias Søn”, "Deelde Byttet blandt de Smaa", "Vinker til”, "os med Seiers-Tegnet" (GVS 1.2, no. 229, 451-452).

70 “Engelen som Lynet”, GSV 1.2, no. 221, 445. Note: Et Græsk Paaske-Vers.

71 "Herren af Søvne opvaagned," GSV 1.2, no. 219, 443-444.

72 "Døden for Ham rømde”, "det er stort, Hvad vor Gud har gjort”, "I de Dødes Rige", "Hulen”, "Herlig Han opstod”, "Adams faldne Kiøn”, "Gravene Han Tømde", "Christus opstod fra de Døde”, "Helvede sprængdes", "Han i sin Død traadte Døden paa Nakke", "Budskab fra Old til Old”, "Christus opstod fra de Døde", "hvert dødeligt Menneske", "Han Reiser dem op fra de Døde" (GSV1.2, no. 221, 445, and no. 219, 443-444).

73 Thodberg 1983, 182.

74 GSV 3.2, no. 176, 330-333.

75 "Paaske-Morgen slukker Sorgen" (GVS 3.2, no. 258, 503). 
the battle is won, because "the Deliverer is Risen." He is "our Redeemer," who "would bleed for us." Now, "Hell is crying, Heaven is rejoicing," for "dead is Death." The strong character of present time is found in the present tense of the last verse: "The Lord we meet, the Lord we meet in new Praise singing!" when "up we rush" together with him. ${ }^{76}$

Many other poetic examples of the theme of Christ's descent to human life and then to Death could be mentioned. It is a strong theme in Grundtvig's theology. In his history writing, too, Grundtvig put Christ's descent and victory into the context of Christian missionary work. Christianity was the most important new thing Ansgar brought to the North (Grundtvig 1865, 39; 41; 44-45).

Questions emerge from Grundtvig's emphasis on themes of Christ's descent, fight, and victory. Will this understanding of Christ open the doors for conversion after death? Is this understanding of Christ a violation of the claim of justice and righteousness? These questions aroused critique of Grundtvig's theme of Christ's descendance into the land of Dead and his preaching for the prisoners. Pietistic groups claimed that, in the moment of death, people faced judgement and were either sent into punishment in Hell or to eternal happiness in Paradise. Many regarded Grundtvig's interpretation of Christ as undermining the claim of conversion to Christ here, now, and before death. This question alone caused the long distance between Grundtvig-inspired groups and revivalist groups. It caused several schisms (Lindhardt 1978, 72;127). And it is evident that Grundtvig's Eastern inspired understanding of atonement is in conflict with what he understands from Western inspired theologies. Very few of his hymns that have the fight-and-victory motif were published in authorized Danish hymnbooks. On the other hand, Grundtvigian congregations emphasized this theme by following the praxis from Grundtvig's Church in Vartov and using the Danish phrase for the Apostolic Creed's discendit ad inferna, instead saying that Christ "descended into Hell." ${ }^{7}$ Grundtvig may have heard the translation "descended into Hell" in Wesley Capel in London where he was a visitor, because Wesley used the same

\footnotetext{
76 "Herrens”, "Mørket”, "Døden”, “Redningsmanden er opstanden”, “vor Forsoner", "vilde bløde for os", "græder Helvede, Himlen sig glæder”, “død er Døden”, "Herren vi møde, Herren vi møde med Lovsang ny!", "vi”, "op vi fare” (GSV3.2, no. $258,503-505)$.

77 "Nedsteget til Helvede."
} 
translation and recommended "into Hell" in his Sunday Service in 1784 (Wesley (1784/1992)). The possibility for conversion after death in Wesleyan theology is not linked to the theme of Christ's descent into the land of the dead, but to the theme of salvation in relation to the grace a person has received (Thaarup 2016, 339-340).

To Grundtvig and to Wesley, Christ's deeds caused the total defeat of corruption, emptiness, death, and the Devil. The good news is liberation for human beings, the opportunity for human beings to go from a life under the dominion of death to a life under the dominion on resurrection, and a life under the conditions of regeneration. In Grundtvig's terminology, the way is opened from death and the land of the dead to the land of the living. ${ }^{78}$ Like Wesley, Grundtvig speaks about eschatological reality as something happening now. The land of the living is the condition Christian people enjoy now, instead of waiting on a coming good from a distant future. Grundtvig's understanding is called "realized eschatology."

Wesley and Grundtvig in final discussion on the theme of Christ's deeds for us

Wesley's writings feature an extended interpretation of Christ's deeds as victories over the powers of death, evil, and corruption. His victory is the basis for human beings' liberation and healing - an interpretation often found in the Eastern tradition (Link 1988, 78). Wesley talks about Christ's deeds as ransom and redemption, language recognizable from written sources that Wesley studied, like the writings of Irenæus, Clement of Alexandria, and Origen or found in The Apostolic Constitution. When Wesley uses the offering motif, he means an offering of liberation like the one found in Exodus; it is not a guilt offering, but an offering as ransom for liberation. Wesley finds support in this use of the offering motif in Makarios and in The Apostolic Constitutions.

Grundtvig uses a number of texts from the Anglo-Saxon tradition to connect to the version of the fight-and-victory motif in the Eastern interpretation of Christ's death and resurrection. For Grundtvig, the Anglo-Saxon tradition was a midway station between Eastern theology and

${ }^{78}$ CP III, 179: "De levendes land." 
Nordic Christianity. He was directly inspired by the dramatic interpretation of Christ's battle with the powers of Death and corruption in the Anglo-Saxon tradition. The fight, victory, and liberation motif found its way from Eastern theology via the Anglo-Saxon inspiration into many of Grundtvig's texts, just as he reused metaphors from Gregory of Nyssa and Gregory the Great.

Wesley and Grundtvig both use more than one interpretation of the atonement (Richardson 1965, 77-90). Wesley says that Christ is the one who has given salvation to sinful human beings, and Christ's sacrifice has an objective value for God's acceptance of human beings which is a way to understand atonement as being in harmony with Anselm's forensic satisfactions hypothesis. Likewise, Grundtvig's contemplative and empathic description of Christ's suffering and death is very much in harmony with Abealard's subjective hypothesis of the atonement. A narrow and limited forensic understanding is not possible for Wesley and Grundtvig, just as the Eastern tradition would never focus only on the forensic dimension of the atonement.

The elements found in Wesley's and Grundtvig's theologies parallel and their convergent thinking do not represent identical theologies. However, common sources in Eastern Greek theology draw the two influential theologians in the same direction, and common sources for inspiration show their ecumenical theological perspectives.

\section{The Morningstar of Christianity}

As mentioned above, my dissertation, The Morningstar of Christianity ${ }^{79}$ analyzes seven themes where Wesley and Grundtvig show inspiration from the Eastern Greek tradition in their theology. This common source of inspiration makes their theologies converge. A further study of the parallel thinking found in Wesley's and Grundtvig's theologies can be found in my post-doctoral dissertation, Enlightened and together with friends we are talk. ${ }^{80}$ In this study, the comparison is done first on the background on both the Deistic theology in England and the Rationalistic theology in

79 Kristendommens Morgenstjerne.

80 "Med venner i lys vi tale." 
Denmark which Wesley and Grundtvig fought when they developed their new European version of Protestant thinking.

\section{Abbreviations}

CP I-III Christelige Pradikener eller Søndags-Bog, 1859-1860, vol. I-III, Copenhagen, Schønberg.

DVI-IV Danne-Virke: et Tidsskrift af N.F.S. Grundtvig (1816-1819), vol. I-IV, Copenhagen, A. Schmidt.

GSV 1.1.-5.2. N.F.S. Grundtvig (1982-1984), Sang-Vark til Den Danske Kir$k e$, Samlet udgave, Copenhagen, Gads Forlag.

GPV 1-VIII Holm, J., Glenthøj, E. \& Thodberg, C. (ed.) (2003-2007), Grundtvig Predikener i Vartov, vol. 6, Kirkeaaret 1843-44, Copenhagen, Vartov.

US I-X Begtrup, H. (ed.) (1904-1909), N.F.S. Grundtvigs Udvalgte Skrifter, Copenhagen, Gyldendal.

CL 1-50 Wesley, J. 1749-55, Christian Library, vol. 1-50, Bristol.

WW 1-27 Wesley, J. (1975-2015), Works. The Bicentennial Edition of the Works of John Wesley, vol. 1-27, Oxford \& Nashville, Abingdon.

\section{Works by Grundtvig}

- (1831), Prospectus for Anglo-Saxon Manuscripts, London.

- (1840), Phenix-Fuglen, Copenhagen, Fabritius de Tengnagels.

- (1855), Om Kiødets Opstandelse og det evige Liv, Copenhagen, Møller.

- (1865), Kong Harald og Ansgar. Rim-Blade af Danmarks Kirke-Bog, Copenhagen, Schønberg.

- (1865), Bjovulus-Drapen, Copenhagen, Schønberg.

- (1875), Krønnike-Rim til levende Skolebrug, Copenhagen, Iversen. 


\section{Bibliography}

Aagaard, A.-M. (1994), Gregor af Nyssa, Frederiksberg, Anis.

Allchin, A.M. (1989), "Grundtvig Seen in Ecumenical Perspective", Grundtvig-Studier 1989-1990.

- (2001), “Descent into Hell”, Grundtvig-Studier 2001.

Anselm (1978 (1090)), Hvorfor Gud blev menneske, translated by Johannes Thulstrup, Copenhagen, C.A. Reitzels.

Aulén, G. (1930), Den Kristna Försoningstanken, Huvudtyper och brytningar, Stockholm, Svenska Kyrkans Diakonistyrelses Bokförlag.

Balslev-Clausen, P. (1983), "Du som går ud fra den levende Gud”, Grundtvig-Studier 1983.

Bede (1955), A History of the English Church and People, translated by Leo SherleyPrice, Edinburgh, Pengiun.

Bradley, S.A.J. (1998), Transcription of the Exeter Book, York, Centre for Medieval Studies.

Christensen-Göransson (1969), Kyrkohistoria 1, Lund, Scandinavian University Books.

Collins, K. (2007), The Theology of John Wesley, Nashville, Abingdon.

Common Prayer, The Book of, London, Clowes \& Sons.

Deschner, J. (1960), Wesley's Christology, Michigan, Francis Asbury Press.

Elbek, J. (1960), Grundtvig og de greske salmer, Copenhagen, Gad.

González, J.L. (1987), A History of Christian Thought, vol. I-II-III, Nashville, Abingdon.

- (1989), Christian Thought Revisited, Three Types of Theology, Nashville, Abingdon.

Gregor of Nyssa (1892), (ed. Schaff Philip), Dogmatic Treatises, New York, Grand Rapids.

Hansen, U. (1953), “Grundtvigs oversættelser af græske salmer”, Grundtvig-Studier 1953.

Hieatt, C. \& Hieatt, A.K. (1967/1983), Beowulf and Other Old English Poems, New York, Bantam.

Holm, B.K. \& Pedersen, E.M.W. (ed.) (2006), Nåden og den frie vilje, Frederiksberg, Anis.

Hymns and Psalms (1983), London, Methodist Publishing House. 
Kjærgaard, J. (2003), Salmehåndbog II, Salmekommentar, Copenhagen, Det Kgl. Vajsenhus' Forlag.

Lindhardt, P.G. (1978), Vakkelse og kirkelige retninger, Aarhus, Aros.

Lindroth, H. (1935), Försoningen. En dogmhistorisk och systematisk undersökning, Uppsala, Lundequistska.

Lindström, H. (1946/1996), Wesley and Sanctification, Uppsala, Acta Upsalatensia.

Link, H.-G. (ed.) (1988), One God, One Lord, One Spirit On the Explication of the Apostolic Faith Today, Geneva, WCC.

Maddox, R.L. (1994), Responsible Grace, Nashville, Abingdon.

Noack, B. (ed.) (1983), Helvedstorm og Himmelfart, Copenhagen, Gad.

- (1989) “Den oldengelske digtning og Grundtvig”, Grundtvig-Studier 1989.

Radler, A. (1988), Kristendomens idéhistoria Från medeltiden till vår tid, Lund, Studentlitteratur.

Richardson, A. (1965), Hur uppstod de klassiska dogmerna?, Stockholm, Verbum.

Salmer \& Sange (2006), Aarhus, Kurér-Forlaget.

Thaarup, J. (2015), Kristendommens Morgenstjerne. Konvergerende teologiske trak med baggrund $i$ østlig tradition hos John Wesley og NFS Grundtvig, Göteborg. (E-book: Göteborgs universitet. ISBN 978-91-628-9546-4 (PDF) https:// gupea.ub.gu.se/handle/2077/41344).

- (2016), Med venner i lys vi tale. John Wesleys og NFS Grundtvigs konvergerende teologier, Strandby, Tro-Fast. (E-book: Forlaget Tro-fast. ISBN 978-87-9082871-4 (PDF). https://www.tro-fast.dk/butikken/506-tro_og_livsstil/10270med_venner_i_lys_vi_tale/).

Thodberg, C. \& Thyssen, A.P. (ed.) (1983), Grundtvig og grundtvigianismen i nyt lys, Frederiksberg, Anis.

WCC, Faith and Order paper no. 153 (1991), Confessing the One Faith, Geneva, WCC.

Wesley, J. (1737/1988), Collection of Psalms and Hymns, Charles-Town/Facsimile Ed., Nashville, Abingdon.

- (1754/1966), Explanatory Notes Upon the New Testament, London, Epworth Press.

- (1765/1975), Explanatory Notes Upon the Old Testament, vol. I-III, Bristol, William Pine/Facsimile Ohio, Ed. Schmul.

- (1784/1992), The Sunday Service of the Methodists in North America, London, Abingdon. 
- (1779/1876), A collection of Hymns, London, Wesleyan Conference.

- (1847), A Collection of Hymns, the Methodist Episcopal Church, New York, Lane \& Tippett.

Wesley, J. \& Wesley, C. (1745), Hymns on the Lord's Supper, Bristol, Felix Farley, (1995 Facsimili Ed. Madison N.J.).

Williams, C.W. (1960), John Wesley's Theology Today, Nashville, Abingdon. 